\title{
Review on Seaweed as Supplement Fish Feed
}

\author{
Mona M Ismail* \\ Taxonomy and Biodiversity of Aquatic Biota, National Institute of Oceanography and Fisheries, Egypt
}

Submission: October 21, 2019; Published: November 20, 2019

Corresponding author: Mona M Ismail, Taxonomy and Biodiversity of Aquatic Biota, Marine Environmental division, National Institute of Oceanography and Fisheries, Alexandria, Egypt

Abstract

The review briefly describing the importance of macroalgae "seaweed" as renewable source of fish feed. Fish aquaculture costs have including investment and operational costs including feed, energy, labor, fuel, oxygen, water, and medicament costs. The feed cost regarding about $40-60 \%$ from fish production. Hence, there is a need to reduce the cost of feed with increasing the growth performance and high survival rate of fish. Seaweed are a shelter for different generations of marine organisms to promote growth and feed efficiency. Moreover, they act as possible alternative protein sources for farmed fish because of their high protein content and productivity. They have been declared as a "super feed", which has significant positive effects on fish performance due to their nutritive and biological values.

Keywords: Macroalgae; Feeding; Fish

\section{Introduction}

Algae are aquatic photosynthetic organisms and the base of food chain. They are the food producing resources that fish are adapted to consume. They can divide into two major groups "microalgae and microalgae (seaweed)" according to their size. Seaweeds are classified into three taxonomic groups: Rhodophyta (red), Chlorophyta (green) and Phaeophyta (brown). They act as a major feed ingredient in nutrional studies and are not considered as an essential fish feed source, but rather as enhancing "standard" feed formulations. Marine macroalgae have been used for healthy feed supplement providing necessary amino acids, beneficial polysaccharides, fatty acids, antioxidants, vitamins and minerals [1,2]. They prefer as food by herbivorous fishes since their stomach have low $\mathrm{pH}$ levels and specialize guts required for the digestion of plant materials [3]. Moreover, they improve the immune system, antiviral, antimicrobial, improved gut function and stress resistance serves as an alternative for fish meal, since their proteins do not contain such high P levels, and they would help to take the pressure off wild fish stocks [4]. There is limited evidence that herbivorous and omnivorous fish ".g. trout, salmon, sea basss and seabream" were more effective at digesting and utilizing seaweed in diet.

Recently, there are many researches have been carried out on the use of seaweed as ingredient for aquafeed for different fish species. Cladophora, Enteromorpha and Ulva species were preferred by Scartichthys viridis (Blennidae) and Sargassum and Dictyota spp. were preferred by Kyphosus spp. (Kyphosidae) and Siganus spp. (Siganidae) [5]. The green seaweed "Ulva and Enteromorpha" exhibited a positive effect on growth performance of rabbit fish fry and reduce of the feed cost as half of the feeding rate with artificial feed, but replacement of artificial feed with fresh seaweeds had negative effect on growth performance of rabbit fish fry [6]. The inclusion of 20-30\% different seaweeds (Cystoseira barbata, Ulva lactuca, U. rigida and Gracilaria cornea) in different species of fish meals decreased all growth performance and feed utilization parameters [7]. The incorporation 5\% of green seaweed Ulva lactuca in Oreochromis niloticus feeds promoted growth, diet utilization, immune response, and body composition of $O$. niloticus [8]. The inclusion of 5\% red seaweed Pterocladia capillacea enhanced some growth performance parameters of European seabass "Dicentrarchus labrax" fry, with an increase in body weight, and weight gain [9]. The carcass lipid levels of $O$. niloticus" tended to increase with increasing levels of Cystoseira meal [10]. The total cholesterol and triglyceride of Lates calcarifer decreased by addition Gracilaria pulvinata this may relate to high algal fiber content and n-3 fatty acids [11].

Macroalgal polysaccharides play vital role in feeding process since they have direct impact on the efficiency of nutrient assimilation in fish gut since polysaccharide can affect digestibility [12]. Alginate extracted from Ascophyllum nodosum etimulated lysozyme activity of Salmo salar [13]. Besides the nutritional value, seaweed contain bioactive compounds which exhibited antimicrobial, antiviral, antioxidative, anti-inflammatory, and neuroprotective so improved the immune response and stress resistance and act as scavenger to reactive oxygen species "ROS" [14]. Fucoidan from Sargassum wightii increased immunological parameters 
such as phagocytic activity, total leucocyte count and respiratory burst activity of Pangasianodon hypophthalmus [15].Inclusion of agar from red seaweed enhanced the survival rate of Aeromonas hydrophila. Interestingly, seaweed act as the major market for astaxanthin so act as pigmentation source in aquaculture [16]. Astaxanthin, a carotenoid equipped with two asymmetric carbon located at the 3 and $3^{\prime}$ position of the benzenoid rings on either end of the molecule. In 1987, the United States Food and Drug Administration approved the use of astaxanthin as a feed additive for aquaculture and subsequently in 1999 astaxanthin where be approved as a nutraceutical. It was the most important carotenoid in salmons and rainbow trouts [17].

\section{Conclusion}

Seaweed or ingredients made of seaweed may be of prime interest for use in fish feed formulations since they are not only profoundly nutritious but also extremely versatile, making them compatible with many foodstuffs already consumed globally. Compared to other aquafeed ingredients, seaweeds are not a supply of nutrients only but also, they are a good source for bioactive compounds that can benefit farmed finfish so they could offer an alternative to the demands of other ingredients used in aquafeed.

\section{References}

1. Guedes A C, Sousa Pinto I, Malcata F X (2015) Application of Micro-algae protein to aquafeed. In: Kim S K (ed.), Handbook of marine micro-algae, Academic Press, Boston, Massachusetts, Pp.93-125.

2. Ismail M M, El Zokm G M, El Sayed AM (2017) Variation in biochemical constituents and master elements in common seaweeds from Alexandria Coast, Egypt, with special reference to their antioxidant activity and potential food uses: prospective equations. Environ Monit Assess 189(12): 648.

3. HornM H, MesserK H (1992) Fish guts as chemical reactor: a model of the alimentary canals of marine herbivorous fishes. Marine Biology 113(4): 527-535.

4. Cyrus M D, Bolton J J, ScholtzR, MaceyB M (2014)The advantages of Ulva (Chlorophyta) as an additive in sea urchin formulated feeds: effects on palatability, consumption and digestibility. Aquaculture Nutrition 21(5): 578-591.

5. Tolentino Pablico G,Bailly N,Froese R and Elloran C (2008) Seaweeds preferred by herbivorous fishes. Journal of Applied Phycology 20(5): 933-938.

6. Abdel Aziz M F A, Ragab M A(2017)Effect of use fresh macro algae (seaweed) Ulva fasciata and Enteromorpha flaxusa with or without artifi- cial feed on growth performance and feed utilization of rabbit fish (Siganus rivulatus) fry. Journal of Aquaculture Research and Development 8: 482 .

7. Abdel WarithA A, YounisE M I,Al Asgah N A (2016) Potential use of green macro-algae Ulva lactuca as a feed supplement in diets on growth performance, feed utilization and body composition of the African catfish, Clarias gariepinus. Saudi Journal of Biological Sciences 23: 404-409.

8. Natify W, Droussi M,Berday A, Araba M (2015)Effect of the Seaweed Ulva lactuca as a feed additive on growth performance, feed utilization and body composition of Nile Tilapia (Oreochromis Niloticus L.). International Journal of Agronomy and Agricultural Research 7 (3): 85-92.

9. WassefE A, El Sayed A FM, Sakr E M (2013) Pterocladia (Rhodophyta) and Ulva (Chlorophyta) as feed supplements for European seabass, Dicentrarchus labrax L., fry. Journal of Applied Phycology 25: 1369-1376.

10. GuroyD, Guroy B, Merrifield D L, Ergun S, TekinayA A, et al (2011) Effect of dietary Ulva and Spirulina on weight loss and body composition of rainbow trout, Oncorhynchus mykiss (Walbaum) during a starvation period.J Anim Physio and Anim Nutr 95(3): 320-327.

11. Morshedi V,Bahabadi M N, Sotoudeh E, Azodi M, Hafezieh M, et al. (2017) Nutritional evaluation of Gracilaria pulvinata as partial substitute with fish meal in practical diets of barramundi (Lates calcarifer). Journal of Applied Phycology 30 (1): 619-628.

12. Sinha AK, Sinha A K, Harinder MakkarH,De Boeck G, Becker K (2012) Nonstarch Polysaccharide in human nutrition- A Review. Crit Rev Food Sci Nutr 52(10): 899-935.

13. Van Doan H, Doolgindachbaporn S, Suksri A (2014) Effects of low molecular weight agar and Lactobacillus plantarum on growth performance, immunity, and disease resistance of basa fish (Pangasius bocourti, Sauvage 1880). Fish \& Shellfish Immunology. 41(2): 340-345.

14. Prabu D L, Sahu N P, Pal A K, Dasgupta S, Narendra A (2016) Immunomodulation and interferon gamma gene expression in sutchi catfish, Pangasianodon hypophthalmus: effect of dietary fucoidan rich seaweed extract (FRSE) on pre and post challenge period. Aquaculture Research 47(1): 199-218.

15..Undeland I (2016) Oxidative stability of seafood. In: Hu M and Jacobsen C (eds.), Oxidative stability and shelf life of foods containing oils and fats, AOCS Press, US, Pp. 391-460.

16. Canales Gomez E, Correa G and Viana MT (2010) Effect of commercial carotene pigments (astaxanthin, cantaxanthin and $\beta$-carotene) in juvenile abalone Haliotis rufescens diets on the color of the shell or nacre. Veterinary Mexico 41: 191-200.

17. Tolasa S, Cakli S, Ostermeyer U (2005) Determination of astaxanthin and canthaxanthin in salmonid. European Food Research and Technology 221: 787-791. 
This work is licensed under Creative

Commons Attribution 4.0 Licens

DOI: 10.19080/OFOAJ.2019.11.555808
Your next submission with Juniper Publishers will reach you the below assets

- Quality Editorial service

- Swift Peer Review

- Reprints availability

- E-prints Service

- Manuscript Podcast for convenient understanding

- Global attainment for your research

- Manuscript accessibility in different formats ( Pdf, E-pub, Full Text, Audio)

- Unceasing customer service

Track the below URL for one-step submission https://juniperpublishers.com/online-submission.php 